\title{
Naproxen, isosorbide dinitrate and co-administration cannot prevent post-endoscopic retrograde cholangiopancreatography pancreatitis: Randomized controlled trial
}

\author{
Fariborz Mansour-Ghanaei ${ }^{1,2}$, Farahnaz Joukar ${ }^{1,3}$, Ali Akbar Khalesi ${ }^{2}$, \\ Mohammadreza Naghipour ${ }^{2}$, Masood Sepehrimanesh ${ }^{3,4}$, Kourosh Mojtahedi ${ }^{2,3}$, \\ Sara Yeganeh ${ }^{1,3}$, Hamid Saeidi Saedi ${ }^{1}$, and Saba Fakhrieh AsI $^{2}$ \\ ${ }^{1}$ GI Cancer Screening and Prevention Research Center, ${ }^{2}$ Caspian Digestive Disease Research Center, \\ ${ }^{3}$ Gastrointestinal and Liver Diseases Research Center, Guilan University of Medical Sciences, Rasht, Iran, \\ ${ }^{4}$ New Iberia Research Center, University of Louisiana, Lafayette, LA, USA
}

\begin{abstract}
Backgrounds/Aims: Acute pancreatitis is the most widespread complication of endoscopic retrograde cholangiopancreatography. Here, we investigated the efficacy of rectal suppository naproxen, sublingual isosorbide dinitrate and their co-administration in the prevention of post-ERCP pancreatitis. Methods: This double-blind randomized clinical trial carried out from June 2015 to February 2016 at the Gastrointestinal and Liver Diseases Research Center in Rasht, Iran. A total of 585 patients were selected from candidates for diagnostic or therapeutic ERCP by using the simple sampling method. Patients divided into three groups. Group A received $500 \mathrm{mg}$ naproxen, group B took $5 \mathrm{mg}$ isosorbide dinitrate, and group $\mathrm{C}$ was co-administrated both agents before ERCP. The primary outcome measure was the development of pancreatitis onset of pain in the upper abdomen and increase of serum amylase activity more than 3 times over the upper normal limit (60-100 IU/L) within first the $24 \mathrm{~h}$ post-ERCP. Results: Totally, 80 patients developed PEP included $29(4.9 \%), 24(4.1 \%)$, and $27(4.6 \%)$ patients in groups A, B, and C, respectively $(p=0.845)$. Longer ERCP time $(p=0.041)$, using diazepam $(p=0.033)$, a higher number of pancreatic ducts cannulation $(p<0.001)$, pancreatic duct injection $(p=0.013)$, and using pancreatic stent $(p=0.004)$ were the predisposing factors for PEP. Conclusions: Our findings indicated that prophylactic naproxen suppository or isosorbide dinitrate sublingually or co-administration had no significant difference in the prevention and severity of PEP, however, enhancing the endoscopist's skills can be effective. Departments and educational hospitals should develop their assessment and quality assurance measures for the training of fellows' not only technical training but also an understanding of the diagnostic and therapeutic roles of the procedure. (Ann Hepatobiliary Pancreat Surg 2020;24:259-268)
\end{abstract}

Key Words: ERCP; Pancreatitis; Naproxen; Isosorbide dinitrate

\section{INTRODUCTION}

Endoscopic retrograde cholangiopancreatography (ERCP) is one of the most effective techniques in the diagnosis and treatment of biliary ducts and pancreas disorders. ${ }^{1}$ However, this technique is accompanied by certain complications and among them, pancreatitis is the most common and serious ones. Post-ERCP pancreatitis (PEP) iden- tified as clinical signs of acute pancreatitis after ERCP with elevated levels of pancreatic enzymes. ${ }^{2}$ Despite significant advances in endoscopic technology, a subsidiary of ERCP and learn how to use it, the prevalence of PEP is steady during the past 30 years. $^{3}$ Incidence of PEP is varied from $0.4 \%$ to $5.4 \%$ of patients depending on the risk factors and the indication of $\mathrm{ERCP}^{4}$ and totally $0.4-0.6 \%$ of patients showed severe PEP which needs en-

Received: February 8, 2020; Revised: April 30, 2020; Accepted: April 30, 2020

Co-Corresponding author: Farahnaz Joukar

Gastrointestinal and Liver Diseases Research Center, Guilan University of Medical Sciences, Sardar Jangle Ave, Razi Hospital, Rasht 4144895655, Iran

Tel: +98-(13)-33535116, Fax: +98-33534951, E-mail: farajov@gmail.com

Co-Corresponding author: Sara Yeganeh

GI Cancer Screening and Prevention Research Center, Guilan University of Medical Sciences, Sardar Jangle Ave, Razi Hospital, Rasht 4144895655, Iran

Tel: +98-(13)-33519248, Fax: +98-33534951, E-mail: Yeganeh_sara6@yahoo.com

Copyright (C) 2020 by The Korean Association of Hepato-Biliary-Pancreatic Surgery

This is an Open Access article distributed under the terms of the Creative Commons Attribution Non-Commercial License (http://creativecommons.org/ icenses/by-nc/4.0) which permits unrestricted non-commercial use, distribution, and reproduction in any medium, provided the original work is properly cited. Annals of Hepato-Biliary-Pancreatic Surgery • pISSN: 2508-5778 - elSSN: 2508-5859 
doscopic or surgical interventions..$^{5}$ Diagnosis of PEP is based on both clinical and laboratory findings and defined and characterized mostly using Cotton criteria. Mild PEP is defined as abdominal pain that needs hospitalization or hospitalization's extension for 2-3 days and elevation of serum amylase activity more than 3 times over the upper limit of normal 24 hours after ERCP. Moderate and severe PEP are defined by the hospitalization period of 4-10 and more than 10 days, respectively. Also, severe PEP is accompanied by certain complications such as necrosis or pseudocyst and sometimes need drainage or surgery as interventions. $^{6}$

Although several endoscopic and pharmacologic strategies have been reported for prevention or reducing the occurrence of PEP, ${ }^{7-14}$ there are controversies about their effectiveness. In the present study, we aimed to evaluate and compare the therapeutic effects of administration of naproxen as a suppository, isosorbide dinitrate as sublingual and their combination in the prevention of PEP.

\section{MATERIALS AND METHODS}

\section{Patients}

In a double-blinded randomized clinical trial (IRCT 201409251155N22), all patients with age more than 16 years who referred for ERCP to Gastroenterology ward of Razi hospital as a referral center of the Rasht, the capital of Guilan province, from June 2015 to February 2016 were enrolled. Patients with acute pancreatitis in the recent two weeks, history of chronic pancreatitis, previous sphincterotomy, consumption of non-steroidal anti-inflammatory drugs (NSAIDs) or nitrate in the recent week, and contraindications of administration of NSAIDs or nitrate such as renal failure, peptic ulcer with recent hemorrhage, hypotension, sensitivity to one of both drugs and lack of satisfaction to precipitation in the study were excluded. The sample size of 202 patients for each group was calculated based on the previous report ${ }^{15}$ and consideration of $p=0.06, \alpha=0.05$, and $\beta=0.1$ using the following formula:

$$
N=\frac{2\left(Z_{1-\frac{\alpha}{2}}+Z_{1-\beta}\right)^{2}\left(P_{2}-P_{1}\right)}{\left(P_{1}-P_{2}\right)^{2}}
$$

After providing informed consent, randomization was performed using a random block (https://www.sealedenvelope.com/simple-randomiser/v1/lists). Patients, physicians, and nurses who administered treatment were unaware of the nature of the drugs. The protocol was approved by the Ethical Committee of Guilan University of Medical Sciences (Reference number: 1930175708) and followed the Helsinki Declaration of 1975, as revised in 2000 (available at http://www.wma.net/e/policy/17-c_e. html).

\section{Grouping and interventions}

Totally, 606 patients were allocated into groups A, B, and $\mathrm{C}$, respectively and received the following treatments immediately before the ERCP:

- Group A: $500 \mathrm{mg}$ rectal suppository naproxen (Behvazan Co., Iran)

- Group B: 5 mg sublingual isosorbide dinitrate (UCB Pharma GmbH, Germany)

- Group C: $5 \mathrm{mg}$ sublingual isosorbide dinitrate and $500 \mathrm{mg}$ rectal suppository naproxen

ERCP was done using a standard therapeutic duodenoscope (EXERA CV-160, Olympus CO.) when the patient was under local anesthesia with $2 \%$ lidocaine and after premedication by intravenous administration of $0.05 \mathrm{mg} /$ $\mathrm{kg}$ of Midazolam or in cases with a contraindication, intravenous administration of $1 \mathrm{mg} / \mathrm{kg}$ pethidine. This condition was indefeasible, except in certain cases, that needs changes. Blood pressure, heart rate, and oxygen saturation were monitored routinely. Contrast medium (Meglumine Compound 76\%) was injected manually, under fluoroscopic guidance and experienced endoscopists carried out ERCPs.

In Group A, 6 patients and in Group B 15 patients failed ERCP. The reasons for technical and clinical failure of ERCP in both groups were mucosal edema, chronic duodenal ulcer disease, impacted stones, tumor infiltration due to pancreatic cancer, periampullary diverticulum, cardiac arrhythmia and poor cooperation of patient. After excluding patients who were not eligible for analysis, 196, 187 and 202 patients (totally 585 patients) were included in groups $\mathrm{A}, \mathrm{B}$, and $\mathrm{C}$, respectively 


\section{Assessments}

Pancreatitis and its severity were defined based on Cotton criteria ${ }^{6}$ as the onset of pain in the upper abdomen and increase of serum amylase activity more than 3 times over the upper normal limit (60-100 IU/L) within first the $24 \mathrm{~h}$ post-ERCP. The severity of pancreatitis categorized based on the duration of treatment for PEP as mild (2-3 day), moderate (4-10 day) and severe (more than 10 days and/or necessitated surgical or intensive treatment, or contributed to death).

Demographic information includes age and gender plus risk factors, ERCP elements, and follow-up data were collected at the time of the procedure, 2 and $24 \mathrm{hrs}$ after ERCP. Oral intake was allowed for patients who had normal serum amylase after $2 \mathrm{hrs}$ and showed no history of abdominal pain, nausea, and vomiting. ERCP duration, the number of biliary and pancreatic cannulations, findings of the biliary and/or pancreatic duct, presence or absence of juxta-ampullary diverticulum and interventions were recorded. Finally, patients with persistent pancreatitis symptoms more than $48 \mathrm{hrs}$ were evaluated for pancreatitis complications such as abscess, pseudocyst, or flu- id collection by CT-scanning.

\section{Statistical analysis}

Qualitative and quantitative data were reported as frequency (percentage) and mean $\pm \mathrm{SD}$, respectively. Data were analyzed using IBM SPSS Statistics version 23. Associations between qualitative variables were checked using the Chi-square test. One way analysis of variance (ANOVA) was used to compare quantitative data between three groups and Tukey was used as Post-hoc test. $p<$ 0.05 was considered a significant difference.

\section{RESULTS}

Totally, 196 (33.5\%), 187 (32\%) and 202 (34.5\%) patients were assessed in groups $\mathrm{A}, \mathrm{B}$, and $\mathrm{C}$, respectively. The three groups were age-, sex-, and body mass index (BMI)-matched ( $p>0.05$, Table 1). The most common reason for ERCP in our patients was common bile duct stone (370 patients, 63.2\%).

No significant differences were detected between three groups about amylase level before $\operatorname{ERCP}(p=0.147)$, after

Table 1. Comparison of mean $\pm \mathrm{SD}$ and frequency (\%) of age, BMI and sex between three groups

\begin{tabular}{cccccc}
\hline Parameters & & Group A $(\mathrm{n}=196)$ & Group B $(\mathrm{n}=187)$ & Group C $(\mathrm{n}=202)$ & $p$-value \\
\hline Age $($ years $)($ mean \pm SD) & & $61.36 \pm 18.23$ & $61.05 \pm 18.18$ & $61.90 \pm 17.04$ & 0.892 \\
BMI $\left(\mathrm{kg} / \mathrm{m}^{2}\right)($ mean \pm SD) & & $26.50 \pm 15.38$ & $24.48 \pm 4.79$ & $25.04 \pm 5.91$ & 0.165 \\
Sex n $(\%)$ & Female & $128(65.3)$ & $105(56.1)$ & $127(62.9)$ & 0.164 \\
& Male & $68(34.7)$ & $82(43.9)$ & $75(37.1)$ & \\
\hline
\end{tabular}

Group A, $500 \mathrm{mg}$ rectal suppository naproxen; Group B, $5 \mathrm{mg}$ sublingual isosorbide dinitrate; Group C, 5 mg sublingual isosorbide dinitrate and $500 \mathrm{mg}$ rectal suppository naproxen

Table 2. Comparison of frequency (percentage) of pancreatitis, severity of pancreatitis and abdominal pain between three groups

\begin{tabular}{|c|c|c|c|c|}
\hline Parameters & Group A $(n=196)$ & Group B (n=187) & Group C $(n=202)$ & $p$-value \\
\hline Pancreatitis n (\%) & & & & 0.845 \\
\hline Yes $(n=80)$ & $29(14.8)$ & $24(12.8)$ & $27(13.4)$ & \\
\hline No $(\mathrm{n}=505)$ & $167(85.2)$ & $163(87.2)$ & $175(86.6)$ & \\
\hline Severity of pancreatitis $n(\%)$ & & & & 0.647 \\
\hline Mild $(\mathrm{n}=51)$ & $16(55.2)$ & $17(70.8)$ & $18(66.7)$ & \\
\hline Moderate $(n=21)$ & $10(34.5)$ & $4(16.7)$ & $7(25.9)$ & \\
\hline Severe $(n=8)$ & $3(10.3)$ & $3(12.5)$ & $2(7.4)$ & \\
\hline Abdominal pain $\mathrm{n}(\%)$ & & & & 0.328 \\
\hline Yes $(n=78)$ & $26(13.3)$ & $30(16.0)$ & $22(10.9)$ & \\
\hline No $(n=507)$ & $170(86.7)$ & $157(84.0)$ & $180(89.1)$ & \\
\hline
\end{tabular}

Group A, $500 \mathrm{mg}$ rectal suppository naproxen; Group B, $5 \mathrm{mg}$ sublingual isosorbide dinitrate; Group C, $5 \mathrm{mg}$ sublingual isosorbide dinitrate and $500 \mathrm{mg}$ rectal suppository naproxen 
Table 3. Incidence of post-ERCP pancreatitis based on different categorized variables

\begin{tabular}{|c|c|c|c|c|c|}
\hline Variables & & $\begin{array}{c}\text { Group A } \\
196(\%)\end{array}$ & $\begin{array}{c}\text { Group B } \\
187(\%)\end{array}$ & $\begin{array}{l}\text { Group C } \\
202(\%)\end{array}$ & $p$-value \\
\hline n $(\%)$ & Pancreatitis: 80 (13.7) & $29(14.8)$ & $24(12.8)$ & $27(13.4)$ & 0.845 \\
\hline \multicolumn{6}{|c|}{ - } \\
\hline Female $(n=360)$ & 57 & $20(35.1)$ & $18(31.6)$ & $19(33.3)$ & 0.486 \\
\hline Male $(n=225)$ & 23 & $9(39.1)$ & $6(26.1)$ & $8(34.8)$ & 0.899 \\
\hline \multicolumn{6}{|l|}{ Age (years) } \\
\hline$<40(\mathrm{n}=96)$ & 19 & $8(42.1)$ & $4(21.1)$ & $7(36.8)$ & 0.502 \\
\hline$>40(\mathrm{n}=489)$ & 61 & $21(34.4)$ & $20(32.8)$ & $20(32.8)$ & 0.929 \\
\hline \multicolumn{6}{|l|}{ BMI $\left(\mathrm{kg} / \mathrm{m}^{2}\right)$} \\
\hline$<25(\mathrm{n}=289)$ & 41 & $15(36.6)$ & $11(26.8)$ & $15(36.6)$ & 0.681 \\
\hline $25-30 \quad(n=220)$ & 28 & $11(39.3)$ & $9(32.1)$ & $8(28.6)$ & 0.698 \\
\hline$>30(\mathrm{n}=76)$ & 11 & $3(27.2)$ & $4(36.4)$ & $4(36.4)$ & 0.553 \\
\hline \multicolumn{6}{|l|}{ Sphincterotomy } \\
\hline No $(n=58)$ & 8 & $5(62.5)$ & $0(0)$ & $3(37.5)$ & 0.278 \\
\hline Precut papillotomy $(n=74)$ & 10 & $3(30)$ & $4(40)$ & $3(30)$ & 0.856 \\
\hline Sphincterotomy $(\mathrm{n}=453)$ & 62 & $21(33.9)$ & $20(32.2)$ & $21(33.9)$ & 0.841 \\
\hline \multicolumn{6}{|l|}{ Pancreatic duct injection } \\
\hline Yes $(n=28)$ & 10 & $4(40)$ & $3(30)$ & $3(30)$ & 0.390 \\
\hline No $(n=351)$ & 59 & $25(42.4)$ & $10(16.9)$ & $24(40.7)$ & $<0.001$ \\
\hline \multicolumn{6}{|l|}{ ERCP duration (min) } \\
\hline $1-19(\mathrm{n}=82)$ & 8 & $4(50)$ & $3(37.5)$ & $1(12.5)$ & 0.501 \\
\hline $20-39(n=122)$ & 41 & $14(34.2)$ & $8(19.5)$ & $19(46.3)$ & 0.135 \\
\hline $40-59 \quad(n=154)$ & 21 & $6(28.6)$ & $9(42.8)$ & $6(28.6)$ & 0.564 \\
\hline $60-80 \quad(n=34)$ & 10 & $5(50)$ & $4(40)$ & $1(10)$ & 0.110 \\
\hline \multicolumn{6}{|l|}{ Anesthetic drug } \\
\hline Midazolam \& pethidine $(\mathrm{n}=188)$ & 21 & $4(19.1)$ & $5(23.8)$ & $12(57.1)$ & 0.172 \\
\hline Diazepam \& pethidine $(n=19)$ & 3 & $2(66.7)$ & $0(0)$ & $1(33.3)$ & 0.027 \\
\hline Diazepam $(n=16)$ & 5 & $2(40)$ & $1(20)$ & $2(40)$ & 0.306 \\
\hline Fentanyl \& propofol \& midazolam $(\mathrm{n}=88)$ & 17 & $10(58.8)$ & $7(41.2)$ & $0(0)$ & 0.513 \\
\hline Fentanyl \& propofol \& lidocaine $(\mathrm{n}=9)$ & 0 & $0(0)$ & $0(0)$ & $0(0)$ & $\mathrm{NC}$ \\
\hline General anesthesia $(n=5)$ & 1 & $0(0)$ & $1(100)$ & $0(0)$ & 0.171 \\
\hline \multicolumn{6}{|l|}{ Number of attempts to cannulate the papilla } \\
\hline No $(n=204)$ & 24 & $21(87.5)$ & $1(4.2)$ & $2(8.3)$ & 0.604 \\
\hline $1(\mathrm{n}=53)$ & 7 & $0(0)$ & $3(42.8)$ & $4(57.2)$ & 0.353 \\
\hline $2(\mathrm{n}=80)$ & 7 & $1(14.2)$ & $3(42.9)$ & $3(42.9)$ & 0.733 \\
\hline $3(n=87)$ & 13 & $1(7.6)$ & $6(46.2)$ & $6(46.2)$ & 0.355 \\
\hline $4 \leq(\mathrm{n}=161)$ & 29 & $6(20.7)$ & $11(37.9)$ & $12(41.4)$ & $<0.001$ \\
\hline \multicolumn{6}{|l|}{ Number of CBD cannulation } \\
\hline No $(n=82)$ & 11 & $5(45.5)$ & $2(18.2)$ & $4(36.3)$ & 0.330 \\
\hline $1(n=123)$ & 12 & $2(16.6)$ & $5(41.7)$ & $5(41.7)$ & 0.670 \\
\hline $2(n=115)$ & 14 & $5(35.7)$ & $4(28.6)$ & $5(35.7)$ & 0.972 \\
\hline $3(n=150)$ & 24 & $8(33.3)$ & $7(29.2)$ & $9(37.5)$ & 0.900 \\
\hline $4 \leq(n=115)$ & 19 & $9(47.4)$ & $6(31.6)$ & $4(21)$ & 0.650 \\
\hline \multicolumn{6}{|l|}{ Number of pancreatic duct cannulation } \\
\hline No $(n=374)$ & 29 & $8(27.6)$ & $9(31)$ & $12(41.4)$ & 0.990 \\
\hline $1(n=73)$ & 17 & $7(41.2)$ & $4(23.5)$ & $6(35.3)$ & 0.156 \\
\hline $2(n=60)$ & 12 & $3(25)$ & $4(33.3)$ & $5(41.7)$ & 0.155 \\
\hline $3(\mathrm{n}=46)$ & 11 & $4(36.4)$ & $4(36.4)$ & $3(27.2)$ & 0.995 \\
\hline $4 \leq(n=32)$ & 11 & $7(63.6)$ & $3(27.3)$ & $1(9.1)$ & 0.127 \\
\hline \multicolumn{6}{|l|}{ Using pancreatic stent } \\
\hline Yes $(n=24)$ & 8 & $0(0)$ & $3(37.5)$ & $5(62.5)$ & 0.183 \\
\hline No $(n=503)$ & 62 & $29(46.7)$ & $12(19.4)$ & $21(33.9)$ & 0.189 \\
\hline \multicolumn{6}{|l|}{ Juxta-ampullary diverticulum } \\
\hline Yes $(n=30)$ & 5 & $0(0)$ & $3(60)$ & $2(40)$ & 0.429 \\
\hline No $(n=507)$ & 65 & $29(44.6)$ & $12(18.5)$ & $24(36.9)$ & 0.109 \\
\hline
\end{tabular}

Group A, $500 \mathrm{mg}$ rectal suppository naproxen; Group B, $5 \mathrm{mg}$ sublingual isosorbide dinitrate; Group C, $5 \mathrm{mg}$ sublingual isosorbide dinitrate and $500 \mathrm{mg}$ rectal suppository naproxen; NC, not calculated 
$2 \mathrm{hrs}(p=0.396)$ and after $24 \mathrm{hrs}(p=0.808)$. Also, no significant associations between post-ERCP abdominal pain $(p=0.328)$ and pancreatitis $(p=0.845)$ with types of treatment were observed. Although severe pancreatitis included the lowest and mild pancreatitis included the highest percentages of patients with pancreatitis in all three groups, but this difference in the severity of pancreatitis was not statistically significant ( $p=0.647$, Table 2 ). Just one patient died in the follow-up who belonged to sublingual isosorbide dinitrate. All other patients were discharged in good condition without reported side effects.

Incidence of PEP based on different categories in the three groups is presented in Table 3. Higher incidences of PEP was seen in patients of rectal suppository group (group A) who used diazepam \& pethidine as anesthetic drugs $(p=0.027$ ) and had four or more attempts to cannu- late the papilla $(p<0.001)$.

Although no significant differences were detected in the incidence of PEP based on groups and categorized ERCP duration, patients with PEP had higher ERCP time in comparison to patients without PEP $(42.25 \pm 14.88 \mathrm{~min}$ vs. $37.67 \pm 15.25 \mathrm{~min}$ respectively, $p=0.013$ ).

Totally, we found that 80 patients $(13.7 \%)$ suffered from PEP. Comparisons of PEP occurrence based on different patient- and procedure-related variables are presented in Figs. 1, 2, respectively. No significant associations were detected between sex, age and BMI with the occurrence of PEP ( $p=0.055, p=0.056$, and $p=0.873$, respectively). Among procedure-related variables, patients with pancreatic duct injection ( $p=0.013$ ), using pancreatic stent $(p=0.004)$, equal or more than 4 pancreatic ducts cannulation $(p<0.001)$, ERCP duration of $60-80 \mathrm{~min}$

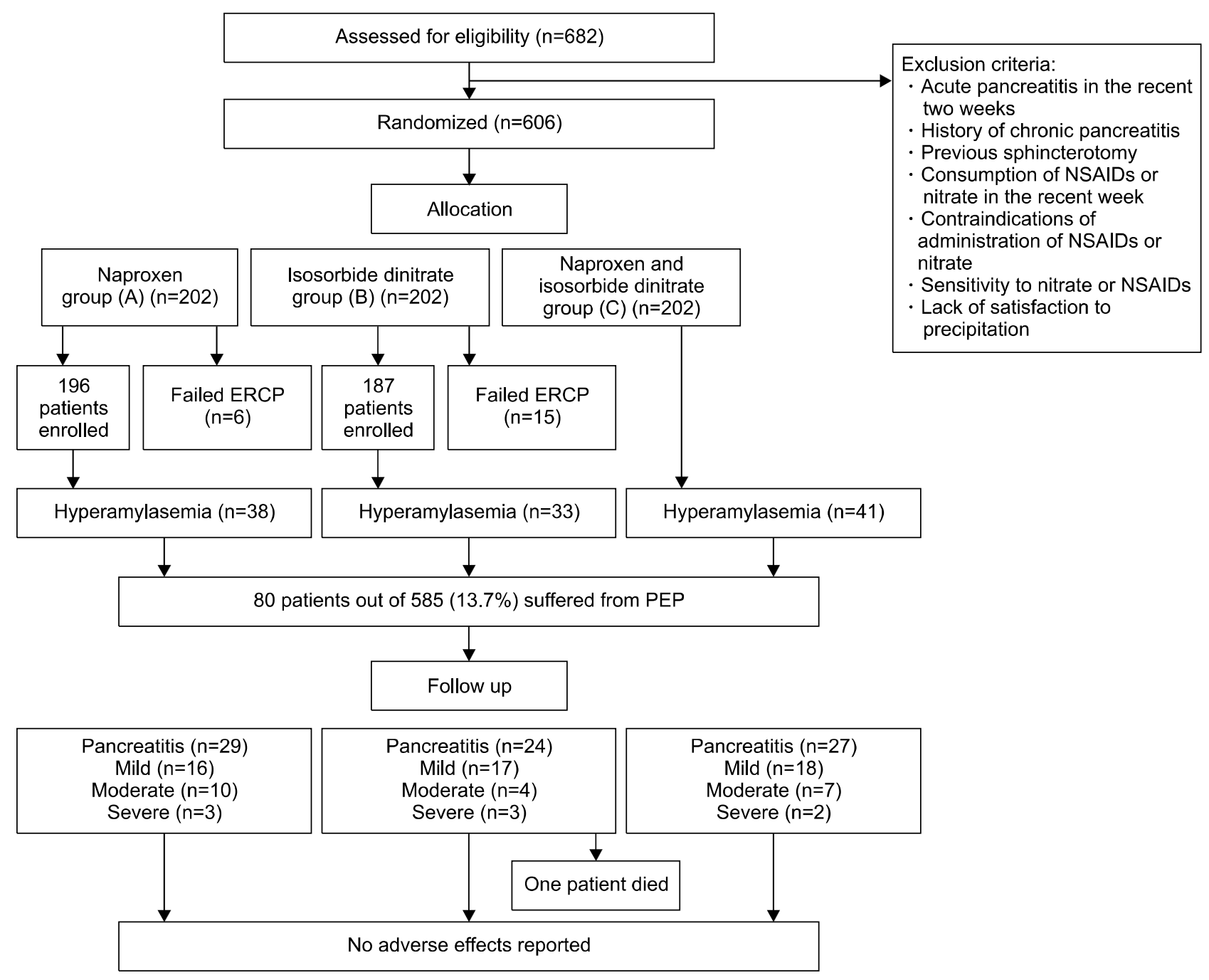

Fig. 1. Flowchart of patients registered in this study. PEP, post-ERCP pancreatitis. 


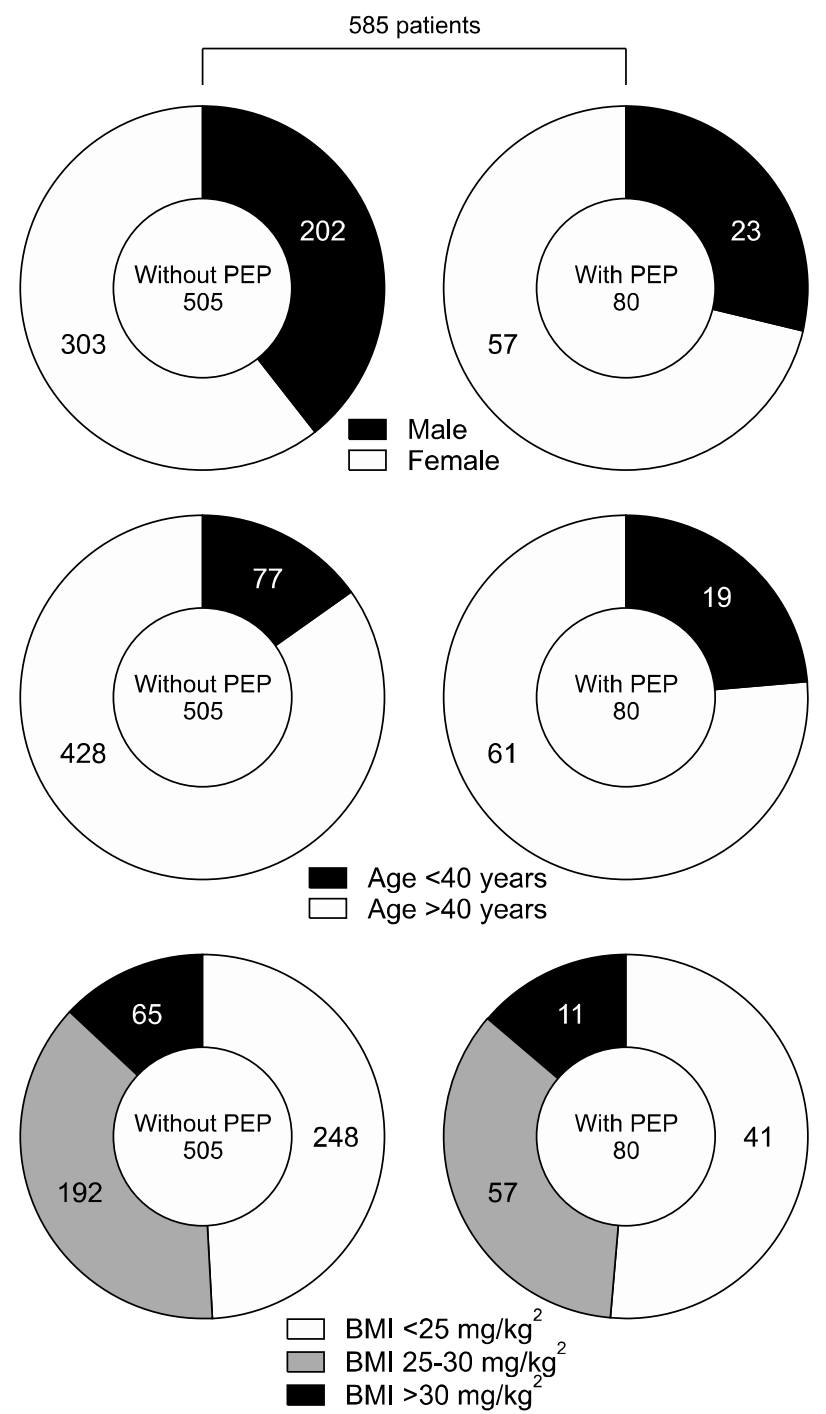

Fig. 2. Comparison of PEP occurrence based on patient-related variables.

( $p=0.041)$, and anesthetized with diazepam $(p=0.033)$ were mostly suffered from PEP (Fig. 3).

\section{DISCUSSION}

In the present RCT, it has been shown that howbeit totally PEP incidence was not changed in response to our administered agents, the frequency of PEP was higher in patients of rectal suppository group without pancreatic duct injection who used Diazepam \& Pethidine as anesthetic drugs with four or more attempts to cannulate the papilla in comparison to other two groups. If all patients considered totally and ignored the patients' groups, pancreatic duct injection, using a pancreatic stent, equal or more than 4 pancreatic ducts cannulation, ERCP duration of 60-80 min, using other methods of sphincterotomy rather than needle-knife, precut or sphincterotomy and anesthetizing with diazepam were predisposed patients to PEP.

Pancreatitis is the most usual severe complication of ERCP. ${ }^{4}$ Our PEP incidence $(13.7 \%)$ is slightly higher in comparison to those reported in the systematic review as $3-10 \%$. However, they reported rates can increase to $15 \%$ or more in high patient- and procedure-related at risks populations. ${ }^{16}$ To prevent PEP some strategies must be attended. These include selecting patients carefully, training of GI man, considering of alternative methods, cannulation under the guide of wire for all patients and using pancreatic duct stent and a single dose of rectal NSAIDs such as indomethacin or diclofenac for high-risk patients. ${ }^{17}$ For the first time, Elmunzer et al. ${ }^{18}$ reported that using rectal indomethacin as a nonsteroidal anti-inflammatory drug (NSAID) could decrease the rate of PEP near $8 \%(9.2 \%$ vs. $16.9 \%$ ) in comparison to placebo. Indeed, NSAIDs inhibit some of the important inflammatory enzymes like cyclooxygenase and phospholipase A2. ${ }^{16}$ After them, several studies were performed about the effects of NSAIDs application in the prevention of PEP with supportive or opposite findings. For instance, in opposite to Elmunzer et al., ${ }^{18}$ Levenick et al. ${ }^{19}$ in a double-blind randomized controlled clinical trial found that rectal indomethacin did not prevent PEP in consecutive patients. Also, the protective efficacy of rectal indomethacin against PEP just confirmed in high-risk patients, ${ }^{20,21}$ rejected in moderate ${ }^{20}$ and low-risk patients. ${ }^{22}$ In a meta-analysis of 6 studies with more than 2400 patients, no significant difference was obtained between indomethacin and placebo administration before ERCP in overall, moderate to severe and mild rates of PEP (OR: 0.67, 0.66 and 0.71, respectively). ${ }^{23}$ In another systematic review of 16 RCTs with a total number of 6458 patients that evaluated the efficacy of rectal NSAIDs with placebo or no treatment in the prevention of PEP, it has been confirmed that rectal NSAIDs decreased the overall risk of PEP. ${ }^{24}$ Moreover, reduce the risk ratio, a number of patients needed to treat, and the decrease of risk ration of moderate to severe PEP by using indomethacin and diclofenac is confirmed by a meta-analysis of 17 trials with the total number of 4741 patients. ${ }^{25}$ Furthermore, among the NSAIDs, diclofenac was acted better than indomethacin ${ }^{24}$ and naproxen. ${ }^{26}$ Howbeit some 

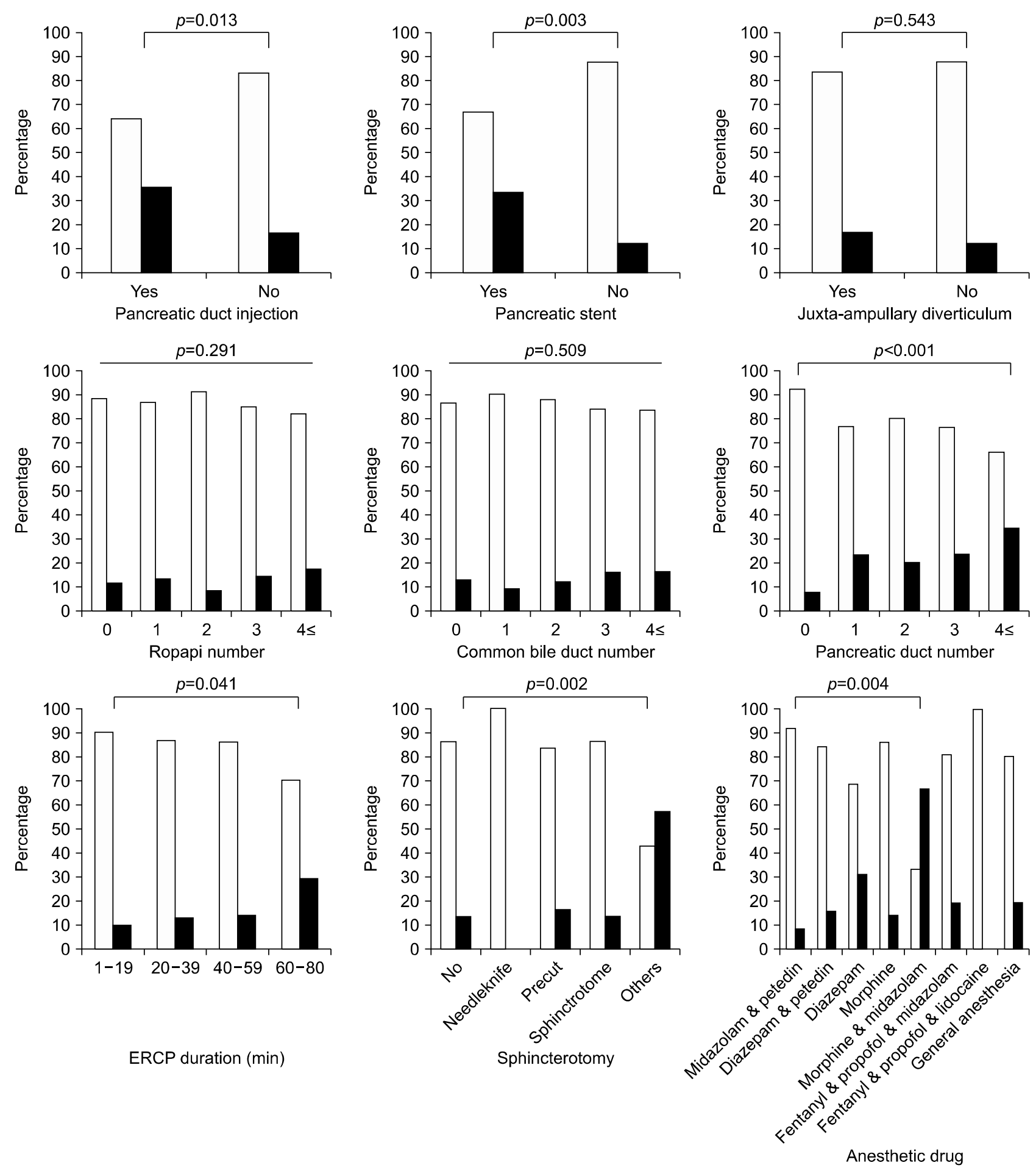

Fig. 3. Comparison of PEP occurrence based on procedure-related variables.

controversies have existed about the superiority of diclofenac against other NSAIDs. ${ }^{25-27}$ We also previously in a double-blind RCT reported that single suppository dose of $500 \mathrm{mg}$ naproxen, as another member of NSAIDs, imme- diately before ERCP decreased the rate of PEP. ${ }^{28}$ Based on all of the above mentioned shreds of evidence, it seems that rectal NSAIDs are effective and safe in the prevention of PEP in all levels of risk. However, our findings 
of the effectiveness of naproxen as one of the NSAIDs are mostly similar to those reported by Levenick et al. ${ }^{19}$ which showed that using naproxen had no beneficial in comparison to other treatments and some cases with special conditions, the rate of PEP was more in the groups who received rectal suppository naproxen.

Despite NSAIDs, there are some other medications, which evaluated their efficacy in the prevention of PEP. These include nitrates, ${ }^{29-31}$ protease inhibitors, ${ }^{13,32}$ somatostatin, ${ }^{33}$ heparin, ${ }^{11}$ allopurinol, ${ }^{8,34}$ secretin, ${ }^{14}$ epinephrine, ${ }^{10}$ neurokinin-1 receptor antagonist, ${ }^{7}$ anti-tumor necrosis factor-a (TNF-a) agent, ${ }^{12} \beta$-carotene, ${ }^{9}$ and intravenous fluid hydration. ${ }^{35}$ One of them is nitrate which administrated through different routes and provides conflicting results ranged from a significant decline ${ }^{29,30}$ to no specific effects ${ }^{36}$ on the occurrence of PEP. The basic mechanism of nitrate's effectiveness is through papillary relaxation and simulate PD placement. ${ }^{37}$ Although the use of nitrates for prevention of PEP is limited due to lack of their efficacy and having serious side effects, ${ }^{29,38}$ one of the recent studies advised the use of nitrates in co-administration with NSAIDs to provide better results of both of them. ${ }^{31}$ We found no significant differences in the occurrence of PEP between three groups and therefore, it can be said that using of sublingual isosorbide dinitrate is effective in the prevention of PEP as well as rectal suppository naproxen and their combination.

As another important finding, a positive association between using pancreatic stent and occurrence of PEP regardless of patients groups was detected. Although, several studies reported that pancreatic stent placement prevented PEP, but it seems that there is controversy in its effectiveness yet. Pancreatic stent placement related adverse events is reported about 4\%. ${ }^{39-41}$ Moreover, in two almost old studies, stent-induced ductal alterations were introduced as cause of chronic pancreatitis-like changes. ${ }^{42,43}$ In light of our additional data about the significant positive relationship between stent and PEP and also based on previous reported chronic pancreatitis as stent complication, we suggested performing the updated study as systematic review and/or meta-analysis covering all newly published RCTs. This can clearly reveal whether postERCP pancreatic stent placement is beneficial for the prevention of PEP or not.

In conclusion, it can be said that prophylactic naproxen suppository or isosorbide dinitrate sublingually or co-administration had no significant difference in the prevention and severity of PEP, however, enhancing the endoscopist's skills can be effective. Departments and educational hospitals should develop their assessment and quality assurance measures for the training of fellows' not only technical training but also an understanding of the diagnostic and therapeutic roles of the procedure including of the indications, risks, benefits, limitations, contraindications, possible adverse events, alternatives to the procedure.

\section{ACKNOWLEDGEMENTS}

The authors wish to thank the staffs of Gastrointestinal and Liver Diseases Research Center of Guilan University of Medical Sciences for their excellent assistance in gathering the patient data and help in performing the laboratory analysis.

The clinical trial registration number in IRCT was IRCT201409251155N22.

\section{CONFLICT OF INTEREST}

There is no conflict of interests.

\section{ORCID}

Fariborz Mansour-Ghanaei: https://orcid.org/0000-0002-6264-0025

Farahnaz Joukar: https://orcid.org/0000-0001-8432-8879

Ali Akbar Khalesi: https://orcid.org/0000-0002-0978-9381

Mohammadreza Naghipour: https://orcid.org/0000-0002-9142-1147

Masood Sepehrimanesh: https://orcid.org/0000-0002-6300-2906

Kourosh Mojtahedi: https://orcid.org/0000-0002-6755-3027

Sara Yeganeh: https://orcid.org/0000-0002-6298-7109

Hamid Saeidi Saedi: https://orcid.org/0000-0002-6848-8693

Saba Fakhrieh Asl: https://orcid.org/0000-0003-3870-4305 


\section{AUTHOR CONTRIBUTIONS}

Conceptualization: FMG, FJ. Data curation: AAK, SFA, KM. Formal analysis: FJ, MS. Funding acquisition: FMG. Methodology: MRN, SY. Project administration: FMG, FJ. Visualization: FMG. Writing - original draft: HSS. MS, SY. Writing - review \& editing: FMG, FJ.

\section{REFERENCES}

1. Taghavi SA, Majd SK, Sianati M, Sepehrimanesh M. Prevalence of IgG-4-associated cholangiopathy based on serum IgG-4 levels in patients with primary sclerosing cholangitis and its relationship with inflammatory bowel disease. Turk J Gastroenterol 2016;27:547-552.

2. Bai Y, Liu Y, Jia L, Jiang H, Ji M, Lv N, et al. Severe acute pancreatitis in China: etiology and mortality in 1976 patients. Pancreas 2007;35:232-237.

3. Woods KE, Willingham FF. Endoscopic retrograde cholangiopancreatography associated pancreatitis: a 15-year review. World J Gastrointest Endosc 2010;2:165-178.

4. Arata S, Takada T, Hirata K, Yoshida M, Mayumi T, Hirota M, et al. Post-ERCP pancreatitis. J Hepatobiliary Pancreat Sci 2010; 17:70-78.

5. Vandervoort J, Soetikno RM, Tham TC, Wong RC, Ferrari AP Jr, Montes H, et al. Risk factors for complications after performance of ERCP. Gastrointest Endosc 2002;56:652-656.

6. Cotton PB, Lehman G, Vennes J, Geenen JE, Russell RC, Meyers WC, et al. Endoscopic sphincterotomy complications and their management: an attempt at consensus. Gastrointest Endosc 1991;37:383-393.

7. Shah TU, Liddle R, Branch MS, Jowell P, Obando J, Poleski M. Pilot study of aprepitant for prevention of post-ERCP pancreatitis in high risk patients: a phase II randomized, double-blind placebo controlled trial. JOP 2012;13:514-518.

8. Zheng M, Chen Y, Bai J, Xin Y, Pan X, Zhao L. Meta-analysis of prophylactic allopurinol use in post-endoscopic retrograde cholangiopancreatography pancreatitis. Pancreas 2008;37:247-253.

9. Lavy A, Karban A, Suissa A, Yassin K, Hermesh I, Ben-Amotz A. Natural beta-carotene for the prevention of post-ERCP pancreatitis. Pancreas 2004;29:e45-e50.

10. Matsushita M, Takakuwa H, Shimeno N, Uchida K, Nishio A, Okazaki K. Epinephrine sprayed on the papilla for prevention of post-ERCP pancreatitis. J Gastroenterol 2009;44:71-75.

11. Barkay O, Niv E, Santo E, Bruck R, Hallak A, Konikoff FM. Low-dose heparin for the prevention of post-ERCP pancreatitis: a randomized placebo-controlled trial. Surg Endosc 2008;22: 1971-1976.

12. Kapetanos D, Kokozidis G, Christodoulou D, Mistakidis K, Sigounas D, Dimakopoulos K, et al. A randomized controlled trial of pentoxifylline for the prevention of post-ERCP pancreatitis. Gastrointest Endosc 2007;66:513-518.

13. Choi CW, Kang DH, Kim GH, Eum JS, Lee SM, Song GA, et al. Nafamostat mesylate in the prevention of post-ERCP pancreatitis and risk factors for post-ERCP pancreatitis. Gastrointest Endosc 2009;69:e11-e18.

14. Jowell PS, Branch MS, Fein SH, Purich ED, Kilaru R, Robuck $\mathrm{G}$, et al. Intravenous synthetic secretin reduces the incidence of pancreatitis induced by endoscopic retrograde cholangiopan- creatography. Pancreas 2011;40:533-539.

15. Cheon YK, Cho KB, Watkins JL, McHenry L, Fogel EL, Sherman S, et al. Frequency and severity of post-ERCP pancreatitis correlated with extent of pancreatic ductal opacification. Gastrointest Endosc 2007;65:385-393.

16. Wang AY. Medications and methods for the prevention of post-ERCP pancreatitis. Gastroenterol Hepatol (N Y) 2017;13: 188-191.

17. Thaker AM, Mosko JD, Berzin TM. Post-endoscopic retrograde cholangiopancreatography pancreatitis. Gastroenterol Rep 2015; 3:32-40.

18. Elmunzer BJ, Scheiman JM, Lehman GA, Chak A, Mosler P, Higgins PD, et al. A randomized trial of rectal indomethacin to prevent post-ERCP pancreatitis. N Engl J Med 2012;366:14141422.

19. Levenick JM, Gordon SR, Fadden LL, Levy LC, Rockacy MJ, Hyder SM, et al. Rectal indomethacin does not prevent postERCP pancreatitis in consecutive patients. Gastroenterology 2016;150:911-917; quiz e19.

20. Inamdar S, Han D, Passi M, Sejpal DV, Trindade AJ. Rectal indomethacin is protective against post-ERCP pancreatitis in high-risk patients but not average-risk patients: a systematic review and meta-analysis. Gastrointest Endosc 2017;85:67-75.

21. Luo H, Zhao L, Leung J, Zhang R, Liu Z, Wang X, et al. Routine pre-procedural rectal indometacin versus selective post-procedural rectal indometacin to prevent pancreatitis in patients undergoing endoscopic retrograde cholangiopancreatography: a multicentre, single-blinded, randomised controlled trial. Lancet 2016;387:2293-2301.

22. Barkin JA, Souto EO, Barkin JS. Rectal indomethacin should be used routinely in all patients for prevention of post-ERCP pancreatitis. Gastrointest Endosc 2017;85:687-688.

23. Feng Y, Navaneethan U, Zhu X, Varadarajulu S, Schwartz I, Hawes R, et al. Prophylactic rectal indomethacin may be ineffective for preventing post-endoscopic retrograde cholangiopancreatography pancreatitis in general patients: a metaanalysis. Dig Endosc 2017;29:272-280.

24. Hou YC, Hu Q, Huang J, Fang JY, Xiong H. Efficacy and safety of rectal nonsteroidal anti-inflammatory drugs for prophylaxis against post-ERCP pancreatitis: a systematic review and metaanalysis. Sci Rep 2017;7:46650.

25. Patai Á, Solymosi N, Mohácsi L, Patai ÁV. Indomethacin and diclofenac in the prevention of post-ERCP pancreatitis: a systematic review and meta-analysis of prospective controlled trials. Gastrointest Endosc 2017;85:1144-1156.e1.

26. Mohammad Alizadeh AH, Abbasinazari M, Hatami B, Abdi S, Ahmadpour F, Dabir S, et al. Comparison of rectal indomethacin, diclofenac, and naproxen for the prevention of post endoscopic retrograde cholangiopancreatography pancreatitis. Eur J Gastroenterol Hepatol 2017;29:349-354.

27. Shen C, Shi Y, Liang T, Su P. Rectal NSAIDs in the prevention of post-endoscopic retrograde cholangiopancreatography pancreatitis in unselected patients: systematic review and metaanalysis. Dig Endosc 2017;29:281-290.

28. Mansour-Ghanaei F, Joukar F, Taherzadeh Z, Sokhanvar H, Hasandokht T. Suppository naproxen reduces incidence and severity of post-endoscopic retrograde cholangiopancreatography pancreatitis: randomized controlled trial. World J Gastroenterol 2016;22:5114-5121.

29. Bai Y, Xu C, Yang X, Gao J, Zou DW, Li ZS. Glyceryl trinitrate for prevention of pancreatitis after endoscopic retrograde cholangiopancreatography: a meta-analysis of randomized, double-blind, placebo-controlled trials. Endoscopy 2009;41:690-695. 30. Chen B, Fan T, Wang CH. A meta-analysis for the effect of pro- 
phylactic GTN on the incidence of post-ERCP pancreatitis and on the successful rate of cannulation of bile ducts. BMC Gastroenterol 2010;10:85.

31. Sotoudehmanesh R, Eloubeidi MA, Asgari AA, Farsinejad M, Khatibian M. A randomized trial of rectal indomethacin and sublingual nitrates to prevent post-ERCP pancreatitis. Am J Gastroenterol 2014;109:903-909.

32. Seta T, Noguchi Y. Protease inhibitors for preventing complications associated with ERCP: an updated meta-analysis. Gastrointest Endosc 2011;73:700-706.e1-e2.

33. Concepción-Martín M, Gómez-Oliva $\mathrm{C}$, Juanes A, Díez X, Prieto-Alhambra D, Torras X, et al. Somatostatin for prevention of post-ERCP pancreatitis: a randomized, double-blind trial. Endoscopy 2014;46:851-856.

34. Romagnuolo J, Hilsden R, Sandha GS, Cole M, Bass S, May $\mathrm{G}$, et al. Allopurinol to prevent pancreatitis after endoscopic retrograde cholangiopancreatography: a randomized placebo-controlled trial. Clin Gastroenterol Hepatol 2008;6:465-471; quiz 471.

35. Buxbaum J, Yan A, Yeh K, Lane C, Nguyen N, Laine L. Aggressive hydration with lactated Ringer's solution reduces pancreatitis after endoscopic retrograde cholangiopancreatography. Clin Gastroenterol Hepatol 2014;12:303-307.e1.

36. Shao LM, Chen QY, Chen MY, Cai JT. Nitroglycerin in the prevention of post-ERCP pancreatitis: a meta-analysis. Dig Dis Sci
2010;55:1-7.

37. Wang AY, Strand DS, Shami VM. Prevention of post-endoscopic retrograde cholangiopancreatography pancreatitis: medications and techniques. Clin Gastroenterol Hepatol 2016;14: 1521-1532.

38. ASGE Standards of Practice Committee, Anderson MA, Fisher L, Jain R, Evans JA, Appalaneni V, et al. Complications of ERCP. Gastrointest Endosc 2012;75:467-473.

39. Deviere J. Pancreatic stents. Gastrointest Endosc Clin N Am 2011;21:499-510, ix.

40. Andriulli A, Forlano R, Napolitano G, Conoscitore P, Caruso N, Pilotto A, et al. Pancreatic duct stents in the prophylaxis of pancreatic damage after endoscopic retrograde cholangiopancreatography: a systematic analysis of benefits and associated risks. Digestion 2007;75:156-163.

41. Freeman ML, Guda NM. Prevention of post-ERCP pancreatitis: a comprehensive review. Gastrointest Endosc 2004;59:845-864.

42. Kozarek RA. Pancreatic stents can induce ductal changes consistent with chronic pancreatitis. Gastrointest Endosc 1990;36: 93-95.

43. Smith MT, Sherman S, Ikenberry SO, Hawes RH, Lehman GA. Alterations in pancreatic ductal morphology following polyethylene pancreatic stent therapy. Gastrointest Endosc 1996;44: 268-275. 